\title{
Revitalisasi Ragam Hias Batik Keraton Cirebon dalam Desain Baru Kreatif
}

\author{
Komarudin Kudiya, Setiawan Sabana, Agus Sachari \\ Institut Teknologi Bandung \\ Jl. Ganesa No. 10 Bandung
}

\begin{abstract}
Respecting traditions of the nation, which is preserving a batik tradition. Cirebon is the region that has a rich cultural treasures batik varied. Given its development, with a variety of Cirebon Kraton, Kraton Batik Cirebon products nowadays have more characteristics, e.g.: (1) Kasepuhan Kraton on Singa Barong's ornament; (2) Kanoman Kraton on Paksi Naga Liman's ornament; (3) Kacirebonan Kraton on Bintulu's ornament and (4) Kaprabonan on Dalung's ornament and motif without pictures of animals.

This research needs to exploring, discovering, and formulating design elements (ornament, material, and color). This study used ethnographic method and experimental visuals method for ornaments on Kraton Batik Kasepuhan, Kanoman, Kaprabonan, and Kacirebonan based on historical cultural influences from Hinduism, Islam, China, and Europe.

As long batik owned by all Cirebon Kraton which is available during this condition can not be identified and their physical condition is damage. Thus in order to preserving the old batiks, it is necessary to reproduce a creative new batik designs with any dimensional aspects.
\end{abstract}

Keywords: Revitalization, Kraton Batik Cirebon, Creative,

\begin{abstract}
ABSTRAK
Dalam kerangka menghargai tradisi suatu bangsa, yaitu melestarikan sebuah tradisi di antaranya berkarya batik, yang merupakan warisan budaya Indonesia. Cirebon adalah wilayah yang memiliki kekayaan khasanah budaya batik yang variatif, baik yang masih tetap ada hingga kini, maupun yang sudah punah. Mengingat di dalam perkembangannya, Keraton Cirebon dengan aneka produk Batik Keraton Cirebon kini terbagi dalam tiga keraton dan satu peguron yang mempunyai ciri khas, antara lain: (1) Keraton Kasepuhan pada ragam hias Singa Barong; (2) Keraton Kanoman pada ragam hias Paksi Naga Liman; (3) Keraton Kacirebonan pada ragam hias Bintulu; (4) Peguron Kaprabonan pada ragam hias Dalung dan motif tanpa gambar hewan.

Perlu dilakukan penelitian untuk menggali, menemukan, dan memformulasikan khususnya unsur teraga (ragam hias termasuk di dalamnya corak, bahan, dan warna). Penelitian ini menggunakan metode etnografi dan eksperimen visual terhadap ragam hias Batik Keraton Kasepuhan, Kanoman, Keprabonan, dan Kacirebonan yang berlandaskan pada kesejarahan mulai dari pengaruh budaya Hindu, Islam, Cina, dan Eropa.

Adapun batik-batik lama yang dimiliki oleh seluruh Keraton Cirebon yang ada selama ini kondisinya tidak bisa dikenali secara umum dan kondisi fisiknya sudah rapuh menuju kondisi rusak. Dengan demikian guna menjaga kelestarian batik-batik lama tersebut maka diperlukan penelitian agar bisa dibuat reproduksinya menjadi desain batik baru kreatif.
\end{abstract}

Kata kunci: Revitalisasi, Batik Keraton Cirebon, Kreatif, 


\section{PENDAHULUAN}

Batik merupakan warisan tradisi budaya yang penting bagi masyarakat Indonesia, akan tetapi desain-desain batik yang dihasilkan selama ini, tidak seluruhnya dapat mengantisipasi kebutuhan gaya hidup kosmopolitan, perdagangan bebas, dan pelestarian lingkungan, terkecuali dalam hal aspek tradisi. Dengan demikian perlu dibuat desain-desain batik yang berorientasi seperti tersebut di atas, dengan tujuan agar bisa bersaing di pasar luar negeri. Berawal dari fenomena kecenderungan gaya hidup kosmopolitan yang ditunjukkan dengan kemampuan daya beli yang tinggi serta hasrat aktualisasi diri memperlihatkan gaya hidup konsumerisme, ditambah dengan diberlakukannya era perdagangan bebas (Pangestu, 1996: 10). Sejalan dengan fenomena tersebut, muncul pula fakta tentang perlunya menghargai tradisi suatu bangsa, seperti yang tercantum di dalam prinsip-prinsip yang terdapat di Piagam Bumi 1992 di Rio de Janeiro Brasil, yang berisikan antara lain meneruskan nilai tradisi dan institusi yang mendukung perkembangan jangka panjang komunitas manusia dan ekologi bumi ke generasi masa depan. Menghargai tradisi suatu bangsa di sini bermakna ikut melestarikan dan menjaga dari sebuah tradisi meliputi arti kebiasaan nenek moyang secara turun-temurun yang masih dilakukan. Dalam hal ini salah satu tradisi yang dimiliki oleh nenek moyang bangsa Indonesia adalah tradisi berkarya dengan media batik.

Dalam kerangka melestarikan tradisi berkarya batik inilah maka Cirebon adalah salah satu wilayah yang memiliki kekayaan khasanah budaya batik yang variatif, baik yang masih tetap ada hingga kini, maupun yang sudah punah. Mengingat di dalam perkembangannya, Keraton Cirebon dengan aneka produk batik (disebut dengan Batik Keraton Cirebon) beserta ragam hias- nya dewasa ini terbagi menjadi empat keraton yang masing-masing mempunyai ciri khas, antara lain: (1) Keraton Kasepuhan pada ragam hias Singa Barong; (2) Keraton Kanoman pada ragam hias Paksi Naga Liman; (3) Keraton Kacirebonan pada ragam hias Bintulu dan motif tanpa gambar hewan; serta (4) Peguron Keprabonan pada ragam hias Dalung.

Namun demikian, situasi kondisi sekarang yang ada dalam ranah pelestarian Batik Cirebonan khususnya Batik Keraton Kasepuhan, Batik Keraton Kanoman, Batik Keraton Kacirebonan, dan Batik Peguron Keprabonan yang seluruhnya digolongkan sebagai Batik Keraton Cirebon di antaranya sebagai berikut: (a) Belum adanya kegiatan yang terfokus pada program pelestarian batik tradisional yang berakar pada batik tradisi keraton (Batik Keraton Cirebon); (b) Masih dirasakan kurang dikenalnya batik-batik tradisional Cirebonan baik secara visual maupun nonvisual (arti dan makna simbol) yang berakar pada batik tradisi keraton di kancah dunia batik nasional maupun internasional; dan (c) Belum tersentuhnya secara maksimal potensi budaya batik tradisional Cirebonan yang cukup besar, yang berada pada wilayah produksi Desa Trusmi, Kalitengah, Wotgali, Gamel, dan Kaliwulu.

Corak Batik Keraton Cirebon yang ada pada saat ini berawal tumbuh-berkembang berada di Keraton Kasepuhan, Kanoman, Kaprabonan dan Kacirebonan. Sejak awal perkembangan batik-batik tersebut telah dipengaruhi oleh budaya Hindu, Islam, Cina, dan Eropa. Kondisi batik-batik kuno yang dimiliki oleh Keraton Kasepuhan, Kanoman, Kaprabonan dan Kacirebonan yang ada selama ini pun kondisinya tidak bisa dikenali secara umum dan kondisi fisiknya sudah rapuh menuju kondisi yang rusak. Ada beberapa perajin batik yang secara turun-temurun turut memproduksi batik-batik keraton ini, namun kondisinya 
kini yang bersangkutan tidak menguasai tentang pemaknaan coraknya serta klasifikasi maupun fungsi dari kain-kain tersebut. Akan tetapi dari investigasi lapangan awal, kemungkinan besar masih bisa didapatkan informasi dari informan atau kerabat dan keluarga keraton yang mengerti tentang makna, filosofi serta mengetahui bagaimana kain-kain tersebut dipergunakan oleh keluarga keraton dari mulai Sultan Sepuh hingga Abdi Keraton. Dengan demikian guna menjaga kelestarian batik-batik kuno tersebut maka diperlukan penelitian agar bisa dibuat reproduksinya menjadi karya batik baru (Batik Cirebonan) dengan metode eksperimen visual terhadap corak Batik Keraton Cirebon.

Tujuan dan manfaat dari penelitian ini, yaitu: (a) Menggali, menemukan, dan memformulasikan unsur desain secara sistematis dari corak Batik Keraton Cirebon; (b) Merancang dan mereproduksi secara benar produk-produk batik kuno yang dimiliki oleh Keraton Kasepuhan, Kanoman, Kaprabonan, dan Kacirebonan. Sekaligus merancang produk baru Batik Cirebonan yang diinspirasi oleh batik-batik kuno dari Keraton Cirebon sebagai upaya revitalisasi; (c) Memberdayakan perajin batik di wilayah produksi Desa Trusmi, Kalitengah, Wotgali, Gamel, dan Kaliwulu Kecamatan Plered Kabupaten Cirebon, agar tidak mudah digeser oleh peran pasar industri kain printing bercorak batik yang ada kini; (d) Menanggapi fenomena pelestarian dan penghargaan atas lingkungan; serta (e) Mengeksplorasi media tradisi melalui desain batik agar dapat bersaing dalam percaturan desain global.

Dalam hal ini revitalisasi menurut Rais (2007), adalah upaya untuk memvitalkan kembali suatu kawasan atau bagian kota yang dulunya pernah hidup, akan tetapi kemudian mengalami kemunduran (dalam hal ini objek revitalisasinya adalah Batik Keraton Cirebon beserta wilayah Keraton
Cirebon itu sendiri). Danisworo (2002) menyebutkan, bahwa pendekatan revitalisasi harus mampu mengenali dan memanfaatkan pula potensi yang ada di lingkungan sekitar seperti sejarah, makna, serta keunikan dan citra lokasi. Sedangkan Laretna (2002) menjelaskan, bahwa dalam pelaksanaan revitalisasi diperlukan adanya keterlibatan masyarakat. Keterlibatan yang dimaksud bukan sekadar ikut serta untuk mendukung aspek formalitas yang memerlukan adanya partisipasi masyarakat, selain itu masyarakat yang terlibat tidak hanya masyarakat di lingkungan tersebut (wilayah produksi Desa Trusmi, Kalitengah, Wotgali, Gamel, dan Kaliwulu Kecamatan Plered Kabupaten Cirebon), melainkan juga masyarakat dalam arti luas.

Membahas tentang revitalisasi, di dalamnya terdapat aspek (sistem) inovasi yang menurut Lundvall (1985), bahwa sistem inovasi merupakan suatu sistem sosial di mana pembelajaran (learning), pencarian (searching), dan penggalian / eksplorasi (exploring) merupakan aktifitas sentral, yang melibatkan interaksi antara orang / masyarakat dan reproduksi dari pengetahuan individual ataupun kolektif melalui pengingatan (remembering).

Sementara ini telah dilakukan observasi langsung (Rohidi, 2011), dilakukan secara langsung dengan cara formal maupun nonformal, untuk mengamati secara kualitatif berbagai kegiatan dan peristiwa seperti dilakukan pada perusahaan batik, toko-toko batik, dan pasar batik. Pada tahap awal sudah dilakukan beberapa kali investigasi lapangan ke Keraton Kasepuhan, Keraton Kaprabonan, Keraton Kanomanan, Keraton Kacirebonan, dan beberapa narasumber yang memiliki data tentang adanya sejarah batik-batik yang ada di lingkungan Keraton untuk menjajaki kemungkinan dilakukan penelitian yang mendalam. Kemudian wawancara dilakukan dengan struktur yang ketat dan formal, juga memilih 
orang-orang yang ahli di dalam bidangnya, agar informasi yang dikumpulkan memiliki kedalaman yang bisa dipertanggungjawabkan. Narasumber yang dimasukkan dalam daftar wawancara penelitian ini: (1) PRA. Arief Natadiningrat, SE. Sultan Sepuh XIV Keraton Kasepuhan; (2) $\mathrm{Hj}$. Ninik Ikhsan, putri dari H. Masina (alm.) sesepuh Batik Trusmi Cirebon; (3) Katura, seniman dan produsen batik tulis tradisional Trusmi Cirebon; (4) Sugeng, penerus Batik H. Madmil, kolektor dan produsen batik tradisional Trusmi Cirebon; (5) Achmad Opan, pelukis kaca dan peneliti filologi bidang naskah-naskah kuno; (6) Dr. H. R. Bambang Irianto, BA., Keturunan Keraton Kacirebonan; (7) Elang Pandji Jaya Prawirakusuma, Keturunan Keraton Kasepuhan; dan seterusnya. Sedangkan dokumentasi dan kumpulan arsip untuk mengumpulkan data yang bersumber dari arsip dan dokumen mengenai perubahan desain batik serta perkembangan penjualan batik untuk wilayah lokal maupun global; adapun pemilik Batik Keraton Cirebon: (1) Keluarga Keraton Kasepuhan, Keraton Kanoman, Keraton Kaprabon, dan Keraton Kacirebonan; (2) Keluarga H. Masina; (3) Keluarga H. Madmil (Sugeng); (4) Keluarga Katura; (5) Keluarga Bres Suhardjo Jakarta; (6) Keluarga Ginandjar Kartasasmita; (7) Koleksi Yayasan Batik Indonesia; (8) Kolektor Batik dari Wastraprema; (9) Museum Nasional; (10) Keluarga H. Santosa Dullah (Danar Hadi); dan seterusnya. Langkah berikutnya dilakukan pembuatan matrikulasi data yang lengkap tentang bahan, corak, ragam hias, warna, komposisi, metafora dan lainlain yang ditemukan setelah dilakukan penelitian. Selanjutnya data yang didapatkan dikompilasi lalu dianalisis, penulisan, pola pemodelan, rekomposisi, rekonstruksi, reproduksi dan produksi karya baru Batik Cirebonan atas dasar tersebut.

\section{METODE}

Metode penelitian yang digunakan adalah metode etnografi (Spradley, 2006), metode estetika, dan metode eksperimen visual (Sachari, 2003) ditunjang dengan pendekatan sejarah yang merupakan cara atau strategi untuk menemukan jawaban atas berbagai permasalahan tentang sejarah sebagai disiplin ilmu: bagaimana masa lalu diketahui, bagaimana bentuk pengetahuan masa lalu, bagaimana objektifitas penulisan sejarah, atau kausalitas dalam sejarah, apakah sejarah bersifat deterministis atau terbuka, dan sebagainya (Yudoseputro, 2005).

Metode etnografi bertujuan mendefinisikan budaya sebagai sistem pengetahuan yang diperoleh manusia melalui proses belajar, yang mereka gunakan untuk menginterpretasikan dunia sekeliling mereka, dan sekaligus untuk menyusun strategi perilaku dalam menghadapi dunia sekeliling mereka. Teknik pengumpulan data yang utama adalah observasi-partisipasi, dan juga wawancara terbuka dan mendalam yang dilakukan dalam jangka waktu yang relatif, bukan kunjungan singkat dengan daftar pertanyaan yang terstruktur seperti pada penelitian survey (Spradley, 2006). Selanjutnya metode estetika dengan aspek desain yang dikaji yaitu wujud visual batik yang dilihat dari bentuk, warna, bahan, ragam hias, corak, yang merupakan unsur-unsur estetika pada Batik Kasepuhan, Kanoman, Kaprabonan, dan Kacirebonan. Sedangkan perancangan baru Batik Cirebonan dengan corak yang berasal dari Batik Keraton Cirebon ini, menggunakan metode eksperimen visual (Sachari, 2003) dengan maksud untuk mengeksplorasi bentuk-bentuk yang ada dari corak tersebut, serta memadukan komposisi bentuk dalam produk batik. Kemudian mengeksplorasi material dan teknik pewarnaan batik dengan menggunakan zat pewarna batik, sebagai upaya revitalisasi ini. 
Salah satu tahapan penting dalam mendesain penelitian yaitu mengidentifikasi suatu metode yang secara tentatif memandu dalam pengumpulan data dan menganalisisnya, baik bagi penelitian kuantitatif maupun kualitatif. Ada beberapa tipe yang dipertimbangkan untuk menetapkan metode kuantitatif, yaitu eksperimen. Dalam pengertian eksperimen ini tercakup eksperimen murni, yaitu dengan menggunakan perlakuan khusus bagi objek atau subjek yang ditetapkan secara random, eksperimen semu yang menggunakan desain nonrandom, dan juga eksperimen semu dengan desain subjek tunggal (Rohendi, 2011).

Mengamati perkembangan batik tahun 1990an hingga kini, dapat dipaparkan kemajuan yang diungkapkan pada aspek rupa, teknik, bahan, proses, dan fungsi, sebagai berikut :

a. Aspek rupa; pada bahan kain batik bisa didapatkan dengan cara memanfaatkan permainan konstruksi benang dalam teknik pertenunan, yang akan menghasilkan tekstur kain yang beraneka macam. Aspek rupa pada kain batik dapat dilihat dari dua pendekatan, yakni melalui pendekatan tekstur dan bentuk ragam hias yang dilukiskan di atas struktur kain. Untuk mendapatkan tekstur kain yang beraneka macam, telah digunakan beberapa serat yang tergolong dalam kelompok serat alam yaitu serat tumbuhan, serat hewan, dan serat mineral. Hal ini dimaksudkan untuk mendapatkan hasil yang bervariasi, dilihat dari tingkat kehalusan, ketahanan, serta kualitas dari kain yang dihasilkan. Aspek rupa juga dapat diungkapkan melalui penentuan bentuk pilihan benang, ketidakteraturan diameter benang, serta penggabungan serat-serat tertentu. Dengan pemilihan serat yang berbeda-beda, maka akan diperoleh nuansa warna yang berbeda, sebab di tiap-tiap serat mempunyai karakteristik yang berbeda, sehingga daya pantul cahayanya akan berlainan. Pada tahun 1999 perkembangan bahan baku sutera yang dihasilkan dari teknik ATBM (Alat Tenun Bukan Mesin) menunjukkan perkembangan yang sangat cepat. Pada saat itu kebutuhan akan benang sutera sangat tinggi, namun sangat disayangkan ketersediaan bahan baku benang lokal sangat terbatas jumlahnya dan sangat tidak mencukupi untuk kebutuhan para penenun kain-kain sutera di Sulawesi Selatan maupun penenun sutera di Jawa Barat. Sedangkan kebutuhan kain sutera putih yang bisa diserap oleh perajin batik di Cirebon, Pekalongan, Solo dan Yogya cukup banyak dan semakin hari semakin meningkat akan jumlah kebutuhan kain-kain tenun sutera ATBM tersebut. Sementara penghasil kain putih sutera ATBM pada saat itu hanya bisa didapatkan dari perajin kain sutera tenun di wilayah Garut dan Ujungpandang saja, sehingga sudah bisa dipastikan masih banyak kekurangan pasokan kain-kain tenun yang bisa diserap oleh para pembatik khususnya yang ada di Jawa Barat dan Jawa Tengah pada umumnya. Untuk memenuhi kebutuhan benang akhirnya didatangkan benang import dari China, sehingga produksi kain sutera ATBM sejak saat itu tidak lagi mengalami kesulitan benang sutera. Dengan terpenuhinya benang sutera maka industri pertenunan menunjukkan hidup kembali, dan dapat menyuplai kain tenun sutera di sentra-sentra produsen batik. Perkembangan teknologi memungkinkan terciptanya berbagai mesin tenun yang mampu merangkum aneka struktur. Perkembangan ke arah inovasi rupa struktur sudah menunjukkan perkembangan yang berarti, dimulai dari perajin tenun ATBM yang telah memodifikasi alat tenunnya, sehingga menghasilkan struktur dan tekstur kain yang beragam. Ada juga yang mengkombinasikan teknik tenun ATBM dengan cara menyulam. Perkembangan yang terakhir telah menunjukkan kemajuan, di mana mesin-mesin 
tenun yang berada di wilayah pertenunan Majalaya yang sebelumnya tidak bisa digunakan untuk menenun kain sutera, sejak tahun 1998 ada beberapa penenun telah memodifikasi mesin tenunnya untuk membuat kain tenun sutera yang cukup bagus. Dari segi pandang lain, aspek rupa dapat diungkapkan melalui bentuk ragam hias. Ada beberapa cara untuk menampilkan aspek rupa batik, seperti pelukisan dengan menggunakan alat canting berbagai ukuran, dengan kuas kain, ada yang menggunakan cap yang terbuat dari tembaga, ada cap yang terbuat dari kayu, ada cap yang terbuat dari susunan paku yang ditempelkan pada batang kayu. Dari teknik pelukisan langsung yang menggunakan sapuan kuas, akan menghasilkan ekspresi khusus berupa tebal-tipis lilin yang melekat pada kain, warna, tekstur, komposisi bidang, irama dan keseimbangan dimunculkan secara spontan. Perupaan batik juga diungkapkan dengan teknik aplikasi atau penambahan materi lainnya. Beberapa desainer pakaian telah memadukan unsur payet atau bebatuan yang dapat dijadikan sebagai tambahan unsur rupa pada kain batik. Ada juga yang melakukan dengan cara membordir bagian-bagian tertentu pada kain batik;

b. Aspek teknik; yang digunakan dalam proses pembuatan batik masih belum menunjukkan perubahan yang berarti, hanya sebatas melengkapi atau menyempurnakan. Teknik batik yang digunakan hanya terbatas pada penggunaan canting serta penggunaan cap. Penggunaan cap sendiri belum ada yang mampu memadukan cap satu dengan yang lainnya bisa disatukan dalam satu gagang, agar didapatkan efesiensi biaya dan waktu. Teknik lain yang digunakan secara umum adalah dengan menggunakan canting yang terbuat dari tembaga. Aspek teknik pada pembuatan kain sutera pada perkembangan terakhir adalah dengan menggunakan mesin jaquard dengan sistem kartu; c. Aspek fungsi; batik bagi bangsa Indonesia dilihat dari fungsinya dapat digolongkan menjadi dua fungsi utama. Di antara fungsi tersebut, yang pertama adalah batik berfungsi sebagai identitas bangsa. Hal ini sudah dibuktikan sejak batik di populerkan sebagai pakaian resmi di Indonesia. Fungsi batik yang kedua adalah sebagai alat penutup bagian anggota tubuh manusia, selain itu pada masa sekarang batik telah digunakan sebagai bahan olahan manusia untuk elemen estetik pada desain interior, cinderamata, dll. (Hasanudin, 1991 : 71).

Revitalisasi diuraikan dalam perkembangan zaman, bahwa objek penelitian Batik Keraton Kasepuhan, Kanoman, Kacirebonan dan Kaprabonan itu sempat kehilangan popularitasnya di awal abad ke19 oleh maraknya bentuk komersialisasi di Cirebon. Usaha-usaha revitalisasi dimulai sejak akhir tahun 2000an, dengan cara menggali kembali dokumen lama berupa batik-batik kuno yang hampir punah untuk direkonstruksi, direproduksi, dan diformulasikan menjadi bentuk karya baru. Batik Keraton Kasepuhan, Kanoman, Keprabon dan Kacirebonan adalah batik-batik yang dibuat di dalam lingkungan keraton oleh keluarga keraton.

Proses produksi batik pada umumnya dimanapun lokasinya hingga saat ini belum mengalami perubahan yang signifikan, dan masih menggunakan langkah-langkah produksi seperti yang terlihat pada bagan 1 .

\section{Kerangka Pemikiran}

Kerangka pemikiran dari pelaksanaan penelitian dapat dijelaskan melalui bagan 2. Adapun keterangan bagan 2 adalah sebagai berikut :

A. Dalam rangka penelitian Revitalisasi Ragam Hias Batik Keraton Cirebon dalam Desain Baru Kreatif (Sebuah Pendekatan Eksperimen Visual), diperlukan upaya un- 


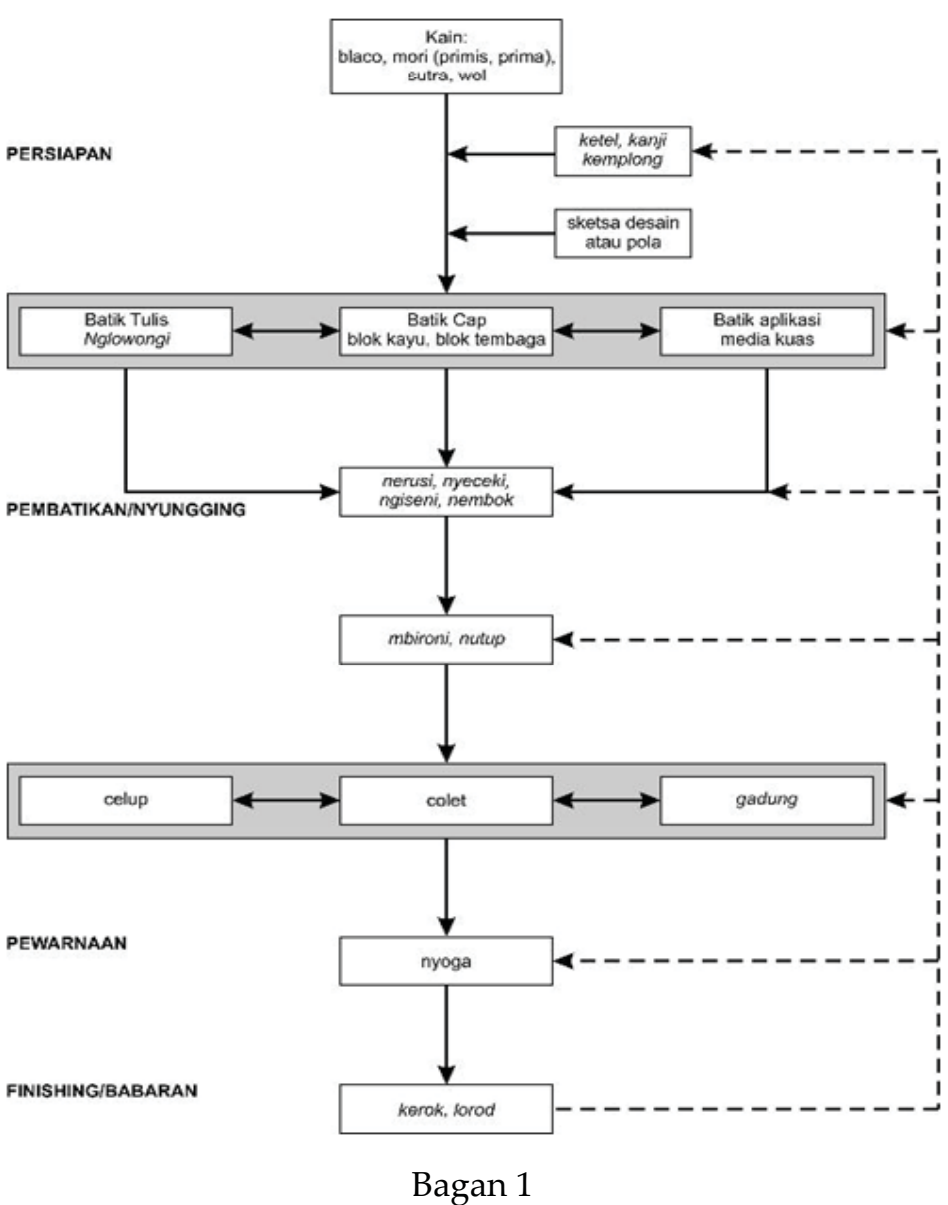

Proses produksi batik tradisional yang akan diterapkan sebagai bagian dalam perancangan batik baru (Kudiya, 2014).

satu ragam hias Taman Teratai yang akan dijadikan objek penelitian lebih lanjut.

D. Dalam penelitian tahap I ragam hias batik Taman Teratai yang ada kemudian di analisa melalui analisis estetik dan analisis historis. Kajian analisis estetis berkaitan dengan unsur karakter visual dan non-visual.

E. Tahap II dilakukan penyusunan konsep desain melalui pendekatan sintesis teori dan sintesis visual. Dalam proses sintesis visual dilakukan analisa tentang warna kain, bentuk kain, tekstur kain, komposisi objek serta ukuran kain-kain batik yang biasa digunakan sebagai busana Keraton.

F. Pada tahap III dilakukan perancangan batik baru, dalam proses perancangan ini dilakukan suatu tahapan

tuk menemukan dokumen/artifak batik lama yang dimiliki oleh Keraton-keraton Cirebon. Di Cirebon terdapat 3 keraton diantaranya Keraton Kasepuhan, Keraton Kanoman, Keraton Kacirebonan dan Peguron Keprabonan.

B. Dokumen berupa foto-foto, sketsa serta kain-kain batik yang didapatkan dari ke 4 lokasi tersebut kemudian dilakukan penelitian terhadap objek ragam hias yang menjadi ide dasar pada perancangan menurut metodologi tertentu yang menyangkut analisis-sintesis.

C. Dari beberapa objek ragam hias yang didapatkan di 4 Keraton tersebut kemudian dilakukan proses sintesa melalui penyebaran kuesioner dengan melibatkan 40 responden dan didukung dengan data awal hasil observasi yang dilengkapi dengan wawancara, akhirnya didapatkan pekerjaan berupa pembuatan sketsa pada kertas minyak atau kertas kalkir dengan tujuan agar didapatkan kualitas gambar yang baik serta ketahanan dokumen bisa bertahan lebih lama. Pembuatan sketsa menggunakan alat tulis rafido dengan ukuran 0,7 $\mathrm{mm}$ berwarna hitam. Dalam proses perancangan dilakukan simulasi desain dengan menggunakan komputer untuk mendapat gambar visual yang diharapkan dapat dilakukan dalam proses produksi selanjutnya. Selain proses simulasi gambar dilakukan upaya pemilihan material untuk eksperimen produksi batik. Bahan-bahan dasar kain yang diujikan diantaranya adalah material kain sutera (lycra, Crep, Chiffon) serta kain katun primissima. Eksperimen dalam proses teknik produksi dilakukan dengan teknik batik cap, teknik batik tulis serta kombinasi teknik cap dan tulis. 


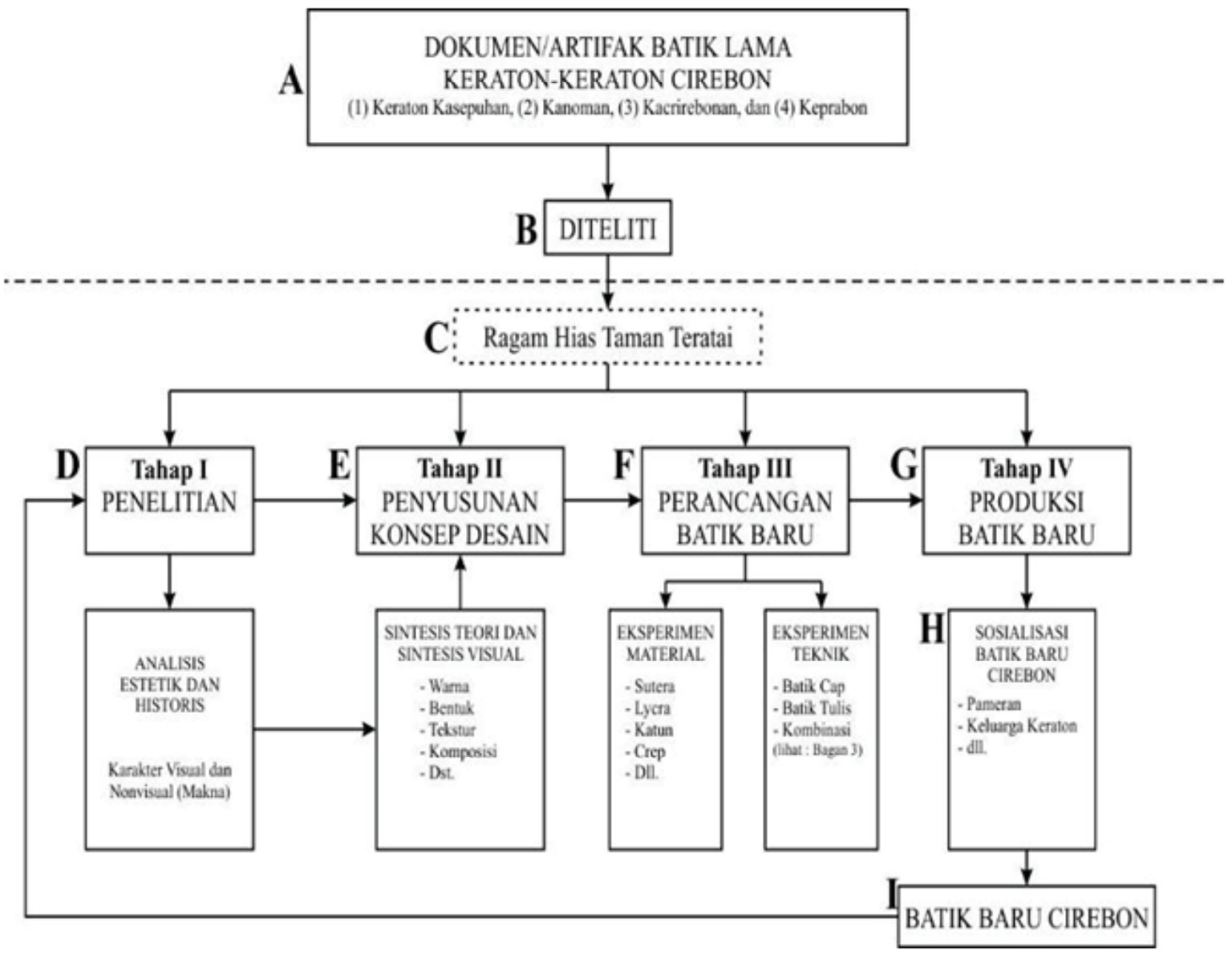

Bagan 2

Kerangka penelitian revitalisasi (Kudiya, 2012).

G. Tahap IV adalah proses produksi batik baru yang didasarkan pada prosesproses sebelumnya. Proses produksi batik baru ini adalah untuk mewujudkan hasil kain batik baru yang didasarkan pada inspirasi dari batik-batik lama keraton. Dalam kegiatan proses produksi batik baru ini dilakukan dengan meningkatkan seluruh proses produksi dan juga memerlukan kualitas bahan-bahan produksi yang lebih berkualitas, sehingga diharapkan tidak hanya sampai batas ragam hiasnya saja, namun juga kualitas secara visual dan nilainilai estetisnya meningkat pula.

H. Ragam hias batik baru tersebut kemudian disosialisasikan secara komprehensif dan berkesinambungan dengan beberapa cara diantaranya adalah melalui dikenakannya oleh keluarga keraton-kera- ton Cirebon, disosialisasikan kepada masyarakat umum melalui publikasi ilmiah, dipamerkan di ruang publik, fashionshow, diskusi ilmiah dan lainnya.

I. Hasil dari sosialisasi tersebut diukur dengan alat ukur diantaranya melalui kuesioner. Hasil yang didapatkan dari desain batik baru tersebut kemudian dianalisa. Bilamana didapatkan temuan serta perlu penelitian lebih lanjut maka proses selanjutnya adalah kembali kepada proses awal.

\section{HASIL DAN PEMBAHASAN}

Batik Keraton Cirebon ialah suatu seni kriya yang dibuat dengan cara melukiskan malam pada sebuah kain, dengan corak-corak tertentu, yang dipergunakan oleh kalangan Keraton Pakungwati/Caru- 
ban Nagari, beserta keturunannya sampai dewasa ini yang tersebar di wilayah Cirebon. Seni batik tradisional Keraton Cirebon adalah keahlian membuat corak atau gambar pada kain yang bermutu tinggi, yang pembuatannya secara khusus selalu berpegang teguh pada adat dan kebiasaan yang ada secara turun-temurun, sejak masa pemerintahan Pangeran Walangsungsang Cakrabuana yang bergelar Sri Mangana pada tahun $1469 \mathrm{M}$, yang kemudian dilanjutkan oleh Syarif Hidayatullah (Sunan Gunung Jati) pada tahun $1479 \mathrm{M}$ hingga kini. Batik Keraton Cirebon sudah berkembang sejak awal perkembangan agama Islam di daerah Cirebon. Batik Cirebon lahir lebih awal daripada batik di Mataram. Dari sejarah pendiriannya, Keraton Cirebon telah berkembang lebih dulu dibandingkan Keraton Mataram yang berkembang di kemudian hari, sehingga kerajinan batik di Cirebon telah berkembang sebelum berdirinya Kerajaan Mataram di Yogya dan Solo. Hal ini diperkuat dengan ditemukannya naskah Sunda yang tertua tentang embrio batik di daerah Cirebon Selatan yang ditulis pada tahun 1440 Saka / 1518 Masehi. Kalaupun ada kemiripan antara batik Cirebon dan batik Yogya dan Solo, bukan berarti batik Cirebon meniru batik Yogya dan Solo, sebab deskripsi sejarah Cirebon, jauh lebih tua daripada Keraton Mataram. Begitu pula bila terdapat penggunaan batik Yogya dan Solo yang digunakan dalam wisuda Jumenengan Sultan Cirebon, itu karena terpaksa atau dipaksa. Hal itu berkaitan dengan kepemimpinan Pangeran Panembahan Adining Kusuma atau Panembahan Ratu Akhir / Panembahan Girilaya, yang naik tahta pada tahun $1649 \mathrm{M}$ dalam status tawanan Raja Mataram Amangkurat I di ibukota Mataram selama tidak kurang dari dua belas tahun hingga wafatnya. Pada saat itu, segala aspek sosial budaya diharuskan berkiblat pada aturan Mataram. (Irianto, dkk. 2012).
Ciri batik dan tatawarna dari Batik Keraton Cirebon khas dengan motif dan tatawarna yang sederhana, pada umumnya setidaknya hanya 3 warna maksimal yang biasa digunakan pada batik-batik. Kain biasanya berlatarbelakang cokelat muda atau gading dan unsur motifnya berwarna khas babarmas, seperti warna pada batik motif Singa Barong, yang mirip kereta aslinya berlapis emas. Ciri umum yang mudah dikenal adalah penonjolan motif-motif utama berupa lambang-lambang yang membawa pesan tertentu, tanpa unsur pelengkap yang mengganggu konsentrasi terhadap motif utama. Tidak ada penambahan unsur yang terlalu padat yang membuat permukaan kain menjadi makin ruwet. Terkadang ada yang diberi latar belakang garis kecil tegak lurus berjarak kurang lebih $1 \mathrm{~cm}$ yang sering kita sebut dengan galaran. Jenis galaran pada kain batik keraton Cirebonan terdapat dua macam yaitu galaran lurus dan galaran engkok/lengkung. Ada pula yang diberi garis tipis yang membentuk motif hias. Hal ini berkaitan dengan teknik pembuatannya yang khas, rumit, dan detail. Contohnya pada batik motif Banjar Balong. Garis-garis yang diberikan pada latar belakang Batik Keraton Cirebon, tidak membuat motif utamanya terbenam, bahkan membuatnya semakin menonjol. Ciri Batik Keraton lainnya menurut Yumiko biasanya bersifat maskulin. Sifat maskulin tersebut disebabkan karena pada awalnya Batik Keraton Cirebon dibuat oleh para lelaki anggota tarekat. Motif batik keratonan biasanya mempunyai pakem-pakem tertentu dan mempunyai ciri yang khas yang terletak pada motifnya. Contoh khas motif Batik Keraton Cirebon sebagian besar menggunakan Wadasan, Megamendung, dan Pandanwangi yang merupakan hiasan pokok Batik Cirebon. Hiasan-hiasan pokok tersebut merupakan pengaruh dari budaya Cina. Ada pula beberapa yang menggunakan ragam hias pohon Lam Alif, Singa Barong, 
Paksi Naga Liman, dan Macan Ali, serta motif lokal tumbuhan rambat seperti kangkung dan lung. Ragam hias pokok motif batik Cirebon didominasi oleh pengaruh Cina yang sudah distilisasikan, namun lebih mengutamakan makna yang terkandung dalam seluruh ragam hias batik Keraton Cirebon. Meskipun motif tersebut merupakan pengaruh budaya Cina, sehingga secara fisik Cina, namun pada perkembangannya motif tersebut ruhnya bernapaskan ajaran Agama Islam. Ruh Islam di dunia Batik Keraton Cirebon merupakan pengejawantahan dari tarekat di Cirebon. Keindahan tarekat dituangkan dalam keindahan motif Batik Cirebon, dengan menyimpan risalah pesan yang secara implisit tertuang dalam corak motif batik (Irianto, dkk. 2012).

Penelitian difokuskan pada revitalisasi unsur estetika berdasarkan kajian etnografis dan historis dari Batik Keraton Cirebon. Kemudian objek penelitian difokuskan pada Batik Keraton Cirebon era dulu dan kini (modern) yang terdapat di kota Cirebon, terdiri atas: Batik Kasepuhan, Batik Kanoman, Batik Kacirebonan, dan Batik Keprabonan. Di dalam Mengamati fakta-fakta yang didapat mengenai berbagai desain Batik Keraton Cirebon berupa amatan corak megamendung dan Wadasan. Dengan demikian, diambil corak Megamendung dan Wadasan ini sebagai ide dasar desain, disebabkan mempunyai aneka ragam, bentuk, komposisi, dan warna. Dengan pertimbangan bahwa corak-corak Batik Keraton Cirebon yang berasal dari empat keraton di Cirebon, pada kenyataannya hingga kini masih diproduksi oleh sebagian masyarakat perajin Batik Cirebonan di wilayah produksi Desa Trusmi, Kalitengah, Wotgali, Gamel, dan Kaliwulu Kecamatan Plered Kabupaten Cirebon. Hal ini terjadi dikarenakan masih banyak para pecinta batik yang menginginkan untuk mengoleksi atau mempergunakan corakcorak tersebut. Corak-corak Batik Keraton Cirebon ini masih sering dicari dan dikena-
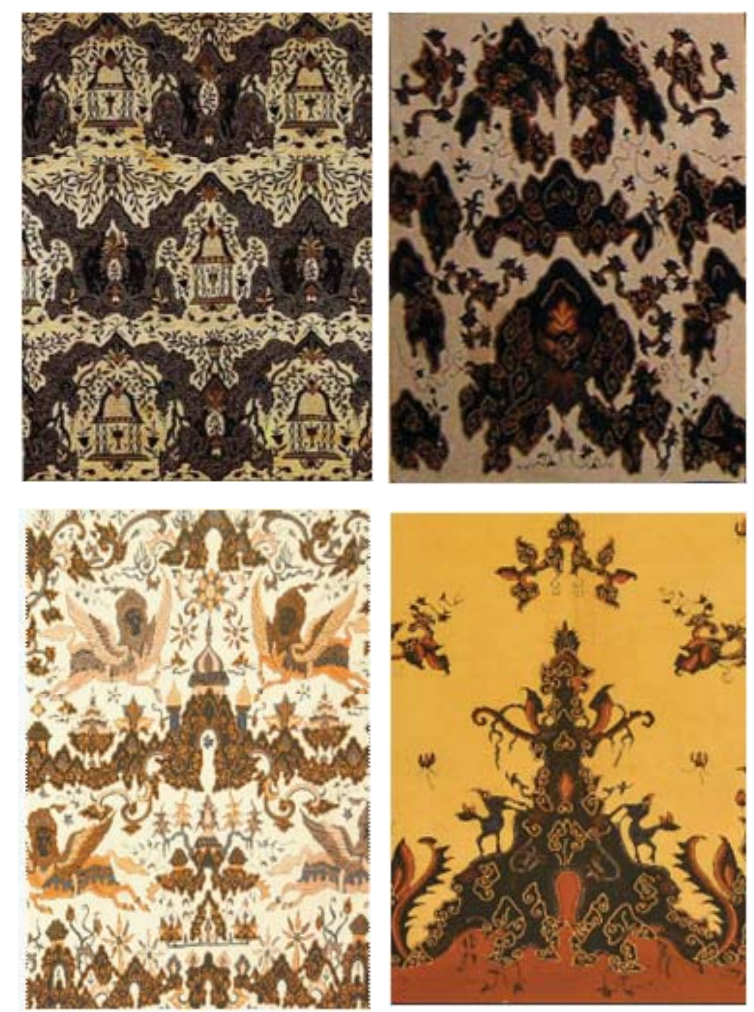

Gambar 1

Ragam hias Wadasan pada Batik Keraton Cirebon (Kudiya, 2009)
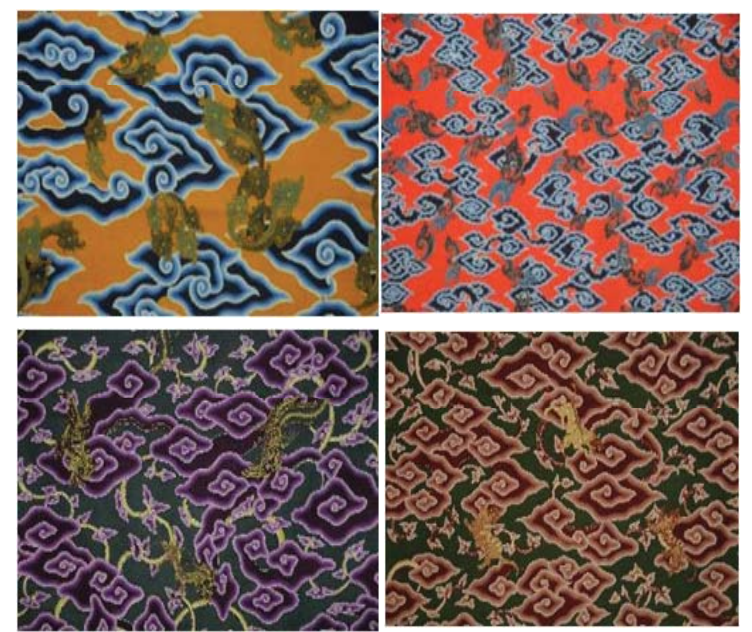

Gambar 2

Ragam hias Megamendung pada Batik Cirebonan hasil dari terapan metode eksperimentasi visual (Kudiya, 2009)

kan oleh sebagian masyarakat keturunan Cirebon sebagai identitas budayanya; yang tidak lain sebagai sarana dalam mengaktualisasi diri terhadap asal daerah mana dan dari strata masyarakat apa berasal 
yang kadang-kala bisa dilihat dari tatacara berbusana, serta di antara tanda-tanda yang mudah untuk dikenali biasanya dari busana yang dipakainya. Di antara sekian banyak jumlah corak Batik Keraton Cirebon, yang sering dipergunakan dan mudah dikenali antara lain adalah Megamendung dan Wadasan.

\section{Batik Baru Cirebonan ragam hias Taman Teratai}

Dari hasil penelitian yang telah dilakukan dengan menggunakan kerangka pemikiran terebut diatas, dan telah dilakukan pengujian dengan menggunakan data kuesioner yang disebarkan kepada responden sebanyak 40 orang yang terdiri dari perwakilan masyarakat perajin batik dan pemerhati batik Cirebonan, didapatlah Taman Teratai sebagai alternatif untuk ragam hias batik Cirebon yang bisa dikembangkan sebagai alternatif ragam hias batik Cirebon yang masih bernuansakan batik-batik yang berasal dari keraton Cirebon.

Rancangan desain batik Taman Teratai tersebut sebelum di wujudkan untuk menjadi kain batik dilakukan tahapan berupa konsultasi dengan Sultan Sepuh XIV PRA Arief Natadiningrat SE beserta perwakilan keluarga keraton Kasepuhan untuk mendapatkan saran serta arahan bagaimana selayaknya hasil rancangan tersebut diproduksi secara nyata dengan kualitas yang baik. Langkah selanjutnya adalah dengan mewujudkan hasil rancangan dan konsep dari penelitian tersebut untuk diwujudkan secara nyata melalui suatu proses pembuatan batik tradisional yang dikerjakan lebih kurang 6 bulan.

Setelah kain tersebut selesai sebelum kain tersebut digunakan untuk acara resepsi pernikahan putri Ratu Raja Fatimah Nurkhayani yang merupakan putri dari Sultan Sepuh XIV, langkah selanjutnya adalah dilakukan proses kurasi yang meli-

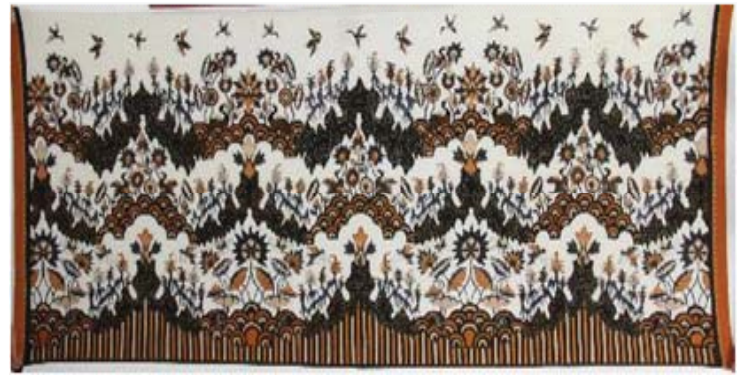

Gambar Kain Panjang

Batik Katun Taman Teratai (Kudiya, 2009)

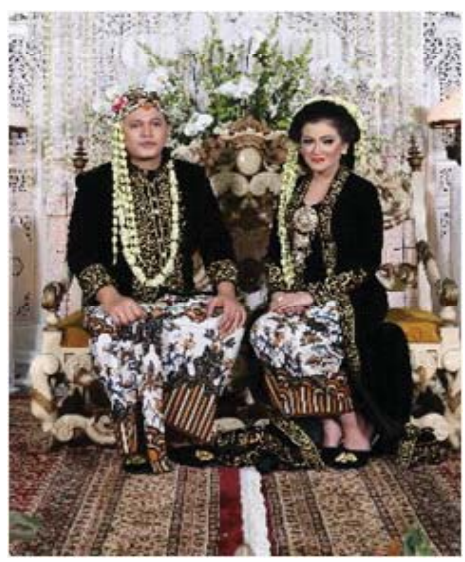

Pasangan pengantin putri Sultan Sepuh XIV Keraton Kasepuhan Cirebon (Kudiya, 2009)

batkan ahli seni dan ahli tekstil yaitu Prof. Biranul Anas Zaman.

\section{PENUTUP}

Simpulan yang didapat antara lain: (a) Proses dalam menggali, menemukan, dan memformulasikan unsur teraga (visual) maupun unsur tak teraga (nonvisual) secara sistematis dari corak Batik Keraton Cirebon, merupakan tantangan tersendiri secara objektif ilmiah hendaknya dapat disusun lebih akurat dan validasi yang tinggi agar tidak terjadi kesalahan dalam aspek kesejarahannya; (b) Proses merancang dan mereproduksi secara benar produk-produk batik kuno yang dimiliki oleh Keraton Kasepuhan, Kanoman, Kacirebonan, dan Keprabonan. Sekaligus merancang produk baru Batik Cirebonan yang diinspirasi oleh 
batik-batik kuno dari Keraton Cirebon sebagai upaya revitalisasi, adalah langkah awal dalam menghadirkan keunggulan kreatifitas Batik Cirebonan dalam konteks kebaruan. (c) Upaya dalam memunculkan ragam hias batik baru dalam bentuk Ragam hias Taman Teratai yang dilakukan dengan perancangan batik baru melalui upaya mengolah komposisi bentuk dan warna diharapkan dapat ditemukan produksi batik baru Cirebon selain ragam hias megamendung dan wadasan yang lebih dulu dikenal di masyarakat luas.

\section{Daftar Pustaka}

A. Sachari

2003 Pengantar Metodologi Penelitian Bu daya Rupa, Desain, Arsitektur, Seni Rupa dan Kriya, cetakan I. Bandung: Penerbit Erlangga

Hasanudin

2001 Batik Pesisiran: Melacak Pengaruh Etos Dagang Santri pada Ragam Hias Batik, Cetakan I. Bandung : PT Kiblat Buku Utama

HR. B. Irianto dan H. Hendriyana

2012 Makna Simbolik Motif Batik Keraton Cirebon, Cetakan I, Gramedia Pustaka Utama

Laretna T. Adhisakti

2003 Draft Program Pelestarian Kawasan Pusaka.
2005 Revitalisasi Kawasan Pusaka di Berbagai Belahan Bumi, Harian Kompas, Minggu, 13November 2005.

Lundvall

1985 'Product innovation and user-producer interaction, industrial development', Research Series 31, Aalborg: Aalborg University Press

Muhammad Danisworo/Widjaja Martokusumo 2000 Revitalisasi Kawasan Kota Sebuah Catatan dalam Pengembangan dan Pemanfaatan Kawasan Kota

Spradley, J. P.

2006 Metode Etnografi, Terjemahan, edisi II cetakan ke-1. Yogyakarta: Tiara Wacana

T. R. Rohidi

2011 Metodologi Penelitian Seni, Cetakan 1. Semarang: Cipta Prima Nusantara

W. Yudoseputro

2005 Historiografi Seni Indonesia, Sebuah Pemikiran Terwujudnya Sejarah Seni Rupa Indonesia, cetakan I. Bandung: Penerbit ITB

webtografi:

http://Hasanmudzakir.mhs.upnyk.ac.id/.../ revitalisasi-kawasan 